\title{
Em teu ventre: quando a ficção é mais verossímil
}

\section{Em teu ventre: when fiction is more verisimilar}

\author{
Ana Cláudia Munari Domingos \\ Universidade de Santa Cruz do Sul, Programa de Pós-Graduação em Letras. Santa Cruz do Sul, RS, Brasil.
}

Doutora em Letras pela PUCRS; Professora Adjunta do Programa de Pós-Graduação em Letras da Universidade de Santa Cruz do Sul - UNISC. da conexão", através do qual estuda a produção literária contemporânea em lingua portuguesa. (iD) https://orcid.org/0000-0002-6629-588X

E-mail: ana.c.munari@gmail.com
RESUMO: A literatura, em sua gênese, tem profundo sentido nos mitos e nas narrativas que explicam o funcionamento do mundo - desde as vozes coletivas e sustentadoras da coletividade, até a lógica da civilização e o sentimento do homem sobre si próprio. A prosa contemporânea, sobretudo o romance, está fundada principalmente nessa última questão, na quebra entre esse mundo e o sujeito. Desde então, memórias coletivas, como as das guerras, e subjetivas, a exemplo de muitas biografias, têm-se dividido entre as principais tendências da escritura, conforme a importância dos acontecimentos e das pessoas que o vivem - ora temos sido mais empáticos com o que nos rodeia, ora somos mais centralizados em questões individuais, marca esta da mentalidade contemporânea. Em Em teu ventre, novela de 2015, o escritor português José Luís Peixoto contraria um pouco essa tendência, ao ficcionalizar uma história que faz parte do imaginário cristão: as aparições de Nossa Senhora em Fátima, Portugal, em 1917. Este trabalho busca compreender o entrelaçamento dos elementos referenciais factuais e a figuração das personagens, bem como a elaboração fictícia, pelo preenchimento dos vazios que a história nunca contou, através da observação do narrador e em torno do significado de memória a partir de Maurice Halbwachs (2004).

Palavras-chave: Em teu ventre; José Luís Peixoto; Verossimilhança; Ficção contemporânea.

ABSTRACT: Literature, in its genesis, has a deep meaning in the myths and narratives that explain the functioning of the world - from collective voices and supporters of the collective, to the logic of civilization and the feeling of man about himself. Contemporary prose, especially the novel, lies in its essence, in the rupture between this world and the subject. Since then, collective memories, as wars, and subjective ones, considering many biographies, have been divided as major trends of writing, according to the importance of events and the people who live them - sometimes more empathic towards what surround us, at times more foccused on individual issues, this is the contemporary mentality. In Em teu ventre, a novel written in 2015, the Portuguese writer José Luís Peixoto contradicts this trend by fictionalizing a story that is part of the Christian imaginary: the apparitions of Our Lady of Fatima, in Fatima, Portugal, in 1917. This essay seeks to understand the interweaving of factual referential elements and the figuration of the characters, as well as fictitious elaboration, by filling the gaps that history has never told, through the observation of the narrator and on the meaning of memory from Maurice Halbwachs (2004)

Keywords: Em teu ventre; José Luís Peixoto; Verisimilitude; Contemporary fiction.

"Este livro é ilusoriamente rápido." (JOSÉ LUÍS PEIXOTO - Feira do Livro de Porto Alegre, 2015) 


\section{Gênesis}

Densei se seria necessário dizer se sou ou não cética em relação ao acontecimento que é cenário da novela Em teu ventre, de José Luís Peixoto, objeto deste trabalho: as aparições de Nossa Senhora, em Fátima, Portugal, no ano de 1917. Os dogmas cristãos estão tão impregnados na cultura ocidental que talvez o fato de eu usar letras maiúsculas na forma de tratamento - Nossa Senhora -, diferentemente do que fez Saramago com caim e deus em uma de suas obras, provocando a ira da Igreja Católica, e de ainda chamar ao evento de acontecimento possam ser interpretados como crença. É necessário dizer que aqui a letra maiúscula também está em História - para justamente diferenciá-la da ficção - então cabe ao leitor crer ou desconfiar, com o acréscimo daquela piscada ao gosto de Umberto Eco (2007).

A linguagem faz isso mesmo, ela instaura realidades: o verbo se fez carne, diz o Gênesis. Pela palavra, Deus criou o mundo - esse Deus cristão que chamou Maria para ser mãe de seu filho: faça-se a luz, e a luz se fez. Segundo diferentes culturas, o mundo, ou o universo, também nasceu das águas, da separação entre céu e terra, de um ovo, do sêmen de um deus. Entre os muitos mitos da criação do mundo, esse que advém da palavra bíblica tem sido reforçado pela fé de todos os cristãos há cerca de dois mil anos.

A Bíblia também tem sua força na palavra, então escrita: para instaurar uma verdade, basta dizer "está escrito". E, assim, se está escrito no livro, então é verdade, pois o livro diz - e dizer, nessa mitologia, é instaurar. Há, ainda, aquele pensamento de que uma "mentira repetida mil vezes se torna verdade", mas esta espécie de dizer está conectada a uma realidade - e a uma memória coletiva - da qual não queremos lembrar - embora devamos - e muito menos transformar em mito. A força da literatura também vem daí, desse poder da linguagem de criar mundos - para o mal ou para o bem:

Macondo era então uma aldeia de vinte casas de barro e taquara construídas à margem de um rio de águas diáfanas que se precipitavam por um leito de pedras polidas, brancas e enormes como ovos préhistóricos. 0 mundo era tão recente que muitas coisas careciam de nome e para mencioná-las se precisava apontar com o dedo (GARCÍA MÁRQUEZ, 2000, p. 7).

E fez-se Macondo, Macondo e seu universo entre os Buendía e os Iguarán. É através das palavras que "o sertão é do tamanho do mundo" (ROSA, 1965, p. 59):

Veredas. No mais, nem mortalma. Dias inteiros, nada, tudo o nada - nem caça, nem pássaro, nem codorniz. 0 senhor sabe o mais que é, de se navegar sertão num rumo sem termo, amanhecendo cada amanhã num pouso diferente, sem juízo de raiz? Não se tem onde se acostumar os olhos, toda firmeza se dissolve. Isto é assim. Desde o raiar da aurora, o sertão tonteia. Os tamanhos. A alma deles (ROSA, 1965, p. 239).

Pensei então se seria necessário estabelecer um paradigma, entre a minha crença e a minha descrença, e assim escolho a verossimilhança, a da literatura, sempre aquela que melhor mente - ser leitor é crer e também desconfiar. "As palavras são corpos transparentes, à espera de uma cor", escreve Peixoto na primeira epígrafe de sua novela, parecendo contrariar a força produtiva das palavras. Mas não é isso: a força está em que justamente o mundo criado por ela se dá translúcido ao leitor, que o pinta conforme as cores do mundo que conhece - sua cultura, seus mitos. $\mathrm{O}$ fato de a palavra, que então apenas sugere, ser capaz de nos fazer erigir mundos pelo exercício do imaginário torna-a ainda mais poderosa. Nesse sentido, ela passa a ser uma força, talvez mesmo uma arma ou uma espécie de magia, que nos permite ordenar ao cérebro que veja, escute e sinta, e que creia nessas imagens. 


\section{Um antigo testamento}

A literatura, em sua gênese, tem profundo sentido nos mitos e nas narrativas que explicam o funcionamento do mundo - desde as vozes sustentadoras da coletividade até a lógica da civilização e o sentimento do homem sobre si próprio. A prosa moderna está fundada sobretudo nessa última questão, na quebra entre esse mundo e o sujeito a partir das transformações que, desde o séc. XVII, modificavam as relações sociais e a consciência do sujeito sobre si e sobre seu agenciamento no mundo. Desde então, memórias coletivas, como as das guerras, e individuais, a exemplo de muitas biografias, têm-se dividido entre as principais tendências da escritura (e do mercado), conforme a importância dos acontecimentos e das pessoas que o vivem - ora temos sido mais empáticos com o que nos rodeia, ora somos mais centralizados em questões individuais. $\mathrm{O}$ individualismo exacerbado - o hipernarcicismo no ver de Lipovetski $(2005,2011)$ - tem sido uma das marcas da mentalidade contemporânea, que coloca o sujeito voltado sobre si mesmo. É exemplo disso a tendência da autoficção, quando os biografemas (BARTHES, 1984, p. 51) do autor são tomados como matéria pertinente para a ficcionalização e transformados em elementos da fábula - quando então não é a memória e sua tentativa de reconstrução linear que advém do exercício da lembrança, mas um pulsar de fragmentos, cujo sentido está na própria ficção, na própria negação da "verdade" da narrativa.

Na obra Em teu ventre, novela de 2015, o escritor português José Luís Peixoto subverte essa tendência contemporânea ao ficcionalizar uma história que, distante do autor, faz parte do imaginário cristão: as aparições de Nossa Senhora em Fátima, Portugal, em 1917. Para contar essa história, há um narrador tradicional das narrativas míticas - onisciente, às vezes na cena, às vezes distante no tempo e no espaço - e também a voz de um criador - Deus? -, além de outros narradores: vozes de mães que se entrelaçam como a se tornarem uma que é a de todas; vozes que vêm de fora do texto e que estavam lá no tempo da narrativa ou em outro tempo da narração essa narração, que é contínua e se encadeia a contar a mesma história, entre mães e filhas e entre mães e filhos. Como nos aponta Halbwachs, "nossas lembranças permanecem coletivas e nos são lembradas por outros, ainda que se trate de eventos em que somente nós estivemos envolvidos e objetos que somente nós vimos" (2006, p. 30). Nesse sentido, a memória de uma mãe é, ainda mais, uma memória coletiva, visto que feita de experiências que envolvem determinados papéis e uma certa tradição - cultural, familiar - do significado de ser mãe.

Em meio às tendências contemporâneas da autoficção e do romancereportagem, misturadas ao volume de textos que fazem do testemunho o mote para a escrita, a novela de Peixoto, publicada em 2015, poderia ser relacionado a um dos mais antigos exercícios da escrita literária: o de refabular textos da cultura (pertencentes a certas tradições míticas, lendárias, históricas) - e a literatura enfim não é exatamente isso? José Saramago, por exemplo, tem entre suas obras vários romances que capitulam sobre a História ou sobre a narrativa bíblica. Na lista dos livros mais vendidos em Portugal, feita pelo jornal Expresso, em 2012 ${ }^{1}$, Saramago figurava com cinco obras que mostram bem essa tendência entre os leitores, gosto que parece prosseguir, vide a retomada dos romances históricos. ${ }^{2}$

Entre essas obras de Saramago está História do cerco de Lisboa (1989), cujo protagonista, um tradutor, apesar de estar em um Portugal do século $\mathrm{XX}$, age sobre um evento do passado - o cerco a Lisboa - ao acrescentar uma palavra à sua tradução. Ao negar a exclusão dessa sua interferência,

${ }^{1}$ Disponível em: <http://expresso.sapo.pt/cultura/Livros/os-50-livros-mais-vendidos-nos-ultimoscinco-anos=f750972>. Acesso em: jul. 2017.

2 Conforme mostra a vídeo-reportagem do Jornal 8, veículo português: <https://www.youtube.com/ watch?v=pGOTDbUcfMk $>$. Acesso em: jul. 2017. 
ele descontrói um dos episódios mais importantes da história da formação de Portugal e dá vida a outro personagem, que passa a ser o narrador, entrelaçando-se as histórias de um na do outro. Também inseridos na lista, duas outras obras de José Saramago, os romances Memorial do convento (1982) e A viagem do elefante (2008), reforçam seu conteúdo histórico. No primeiro, o autor remonta à paisagem da construção do Palácio Nacional de Mafra, o Convento, durante o reinado de D. João XVII. No segundo, é contada, conforme resume o texto de apresentação da Companhia das Letras, editora da obra no Brasil ${ }^{3}$,

a insólita viagem de um elefante chamado Salomão, que no século XVI cruzou metade da Europa, de Lisboa a Viena, por extravagâncias de um rei e um arquiduque. 0 episódio é verdadeiro. Dom João III, rei de Portugal e Algarves, casado com dona Catarina d'Áustria, resolveu numa bela noite de 1551 oferecer ao arquiduque austríaco Maximiliano II, genro do imperador Carlos Quinto, nada menos que um elefante (COMPANHIA DAS LETRAS, s./d.).

Ainda na lista dos mais vendidos, Saramago tem outras duas obras que reconstroem episódios bíblicos, como o Evangelho segundo Jesus Cristo (1991) e Caim (2009). Em ambos Saramago liberta sua escrita para recompor com ironia e simbolismo as narrativas, uma do Antigo e outra do Novo Testamento, transformando Jesus em um homem de carne e osso e, portanto, em um personagem mais verossímil, na primeira obra e, anacronicamente, colocando caim ao lado de noé na segunda. Mas não sejamos tão racionalistas quanto, como disse o anjo, era caim (SARAMAGO, 2009, p. 30): de que anacronia falamos se o próprio Caim viveu, conforme a Bíblia, 910 anos? O Evangelho foi tomado com tanta importância, que as

${ }^{3}$ Disponível em: <https://www.companhiadasletras.com.br/detalhe.php?codigo=12696>. Acesso em: jul. 2017. críticas da Igreja e a sua influência sobre o próprio Estado fizeram com que Saramago fosse viver em Espanha.

Para além da fabulação sobre episódios bíblicos, a temática religiosa ainda está na lista com a obra $O$ céu existe mesmo (2011), livro mais vendido em Portugal em 2011, adaptado para o cinema em 2014. Classificado como autobiográfico, o livro de Todd Burpo e Lynn Vincent narra a história do menino Colton, filho caçula dos autores, que, depois de sobreviver a uma infecção generalizada em vista de uma apendicite, começa a contar a história de sua experiência durante o coma, quando se encontra com várias pessoas que já tinham falecido. Narrativas com um pé mais firme na factualidade um tanto mais provável - mas não menos testemunhal - também estão na lista. É o caso de A estrela de Joana, de Paulo Pereira Cristóvão, que recria a história do desaparecimento, em 2004, da menina Joana, em Portugal, e contada por um dos investigadores do suposto crime. Nesta mesma linha está o livro Maddie, a verdade da mentira (2008), de Gonçalo Amaral, também contada pelo policial que investigava o desaparecimento da menina britânica Madeleine McCann, em 2007, em Portugal. Embora ambos possam ser tomados como testemunhos, não escapam às críticas sobre a falta de verdade e sobre pontos de vista equivocados - não tão distantes daquelas que sofreu Saramago com o seu caim. Ou seja: ficção e história são suscetíveis às mesmas críticas quando a questão é a pontuação tanto de fatos quanto de crenças - testemunhos, provas, tudo se torna verossimilhança pela palavra. Aliás, sabemos: toda mediação é um espaço entre o fato e sua representação.

Outro livro que também foi adaptado para o cinema a partir do sucesso com os leitores, e que está na lista do jornal Expresso, é Comer, orar, amar (2006), catalogado como romance pela Bertrand, editora que o publicou em Portugal, e como "1. Viagens. 2. Escritores de viajantes americanos Biografias", pela Objetiva, no Brasil, onde foi publicado com o título Comer, rezar e amar (2008) Escrito em primeira pessoa por Elizabeth Gilbert como 
um relato de suas viagens pela Itália, Índia e Indonésia, a obra também pode ser lida como "de autoajuda", a partir dos testemunhos da protagonistanarradora e de seus conselhos. Entre o romance e a biografia, conforme diferentes fichas catalográficas, a arquitextualidade da obra de Gilbert depende do leitor.

Um dos escritores mais vendidos em 2012 em Portugal é José Rodrigues dos Santos, autor da série "Tomás Noronha”, que leva o nome de seu protagonista, um professor universitário que investiga relações entre a ciência, a história e a mitologia, procurando a "verdade" entre esses elementos. Por exemplo, em Codex 632 (2005), primeiro volume da série, o protagonista pesquisa a hipótese de Cristóvão Colombo ser português; no segundo, A fórmula de Deus (2006), ele se aventura a descobrir, a partir de um manuscrito do físico Einstein, provas para a existência de Deus; no terceiro volume, $O$ sétimo selo (2007), Noronha se envolve com problemas bastante factuais, como os que dizem respeito ao meio-ambiente e ao cartel do petróleo, e, ainda, sobre a possibilidade de um apocalipse. Em 2011 o escritor, jornalista da emissora RTP, envolveu-se em uma polêmica com a Igreja Católica, ao tentar revelar, em $O$ último segredo (2011), a "verdadeira" identidade de ninguém menos que Jesus Cristo. Em $O$ anjo branco (2010), Santos se aproxima da biografia, homenageando seu pai, que viveu muitos anos em Moçambique, e recontando a história da colonização daquele país.

Entre os mais vendidos também está Rio das flores (2008), de Miguel Souza Tavares, obra sobre a qual se pode dizer que adensa o conteúdo histórico, já que o autor realizou uma intensa pesquisa para compô-la. No entanto, é a partir de uma família fictícia - os Ribera Flores - que o narrador pinta um grande painel entre a Primeira República portuguesa, em 1915, até o fim da Segunda Guerra Mundial, evocando também acontecimentos passados no Brasil. É dessa forma que a História passa a ser o contexto para a narrativa de três gerações que a atravessam e, nesse sentido, embora haja todo um conjunto de elementos para o reconhecimento do leitor, é a experiência subjetiva dos personagens, na ficção, que tece a meada do tempo. Nada melhor do que a literatura para nos relatar verdades humanas.

Esse interesse por histórias, que ora atravessam imaginários, ora penetram no não menos denso terreno da realidade, certamente tem sua origem no próprio nascimento da literatura e no modo como usamos as narrativas para colocar as coisas em ordem. Esse retorno como tendência, tanto em Portugal como no Brasil, de obras que se voltam para questões religiosas ou espirituais - vide o caso das preferências por obras espíritas como as de Zíbia Gasparetto ou os ensaios cristãos como os de Padre Marcelo Rossi - talvez seja explicado pela própria descrença na realidade e, também, pelo modo como ela tem-se confundido com a simulação, a performance, a invenção - meios de experienciar a realidade dessa era cibernética.

\section{Novos testamentos}

Para Halbwachs (2006), a ideia de um passado imutável é inviável, já que os grupos que compartilham memórias as ressignificam o tempo todo a partir de suas crenças e novas vivências e também em vista de novas mentalidades: "o funcionamento da memória individual não é possível sem esses instrumentos que são as palavras e as ideias, que o indivíduo não inventou, mas que toma emprestado de seu ambiente" (HALBWACHS, 2006, p. 72). Na obra de Peixoto, isso se dá de maneira bastante visível, já que o olhar do narrador onisciente sobre o passado é também um olhar emocional, que evoca lembranças de si, sobretudo no diálogo produzido entre uma voz escritural e sua mãe, como explico a seguir.

Uma das formas de entender a novela de José Luís Peixoto a partir de sua relação com a reconstituição de uma memória coletiva - cultura, verossimilhança e mesmo mito (e isso não significa que a narrativa seja 
sobre isso) -, é destecendo sua transtextualidade, as relações transtextuais (GENETTE, 2006), que tanto a obra costura diretamente com outros textos, como aquelas que sua leitura faz evocar. O modo como a obra traz a história da aparição é muito mais denso do que simplesmente uma recontação fabular. 0 acontecimento de 1917 é, na verdade, muito mais um mote para falar de relações humanas, em especial entre mãe e filhos e no contexto da vida rural, do que a fábula em torno da qual se desenvolve a novela. São essas relações transtextuais que tecem essa memória, entre outros textos, outros tempos, outras vozes.

Figuras 1 e 2 - Capas das edições portuguesa e brasileira, respectivamente

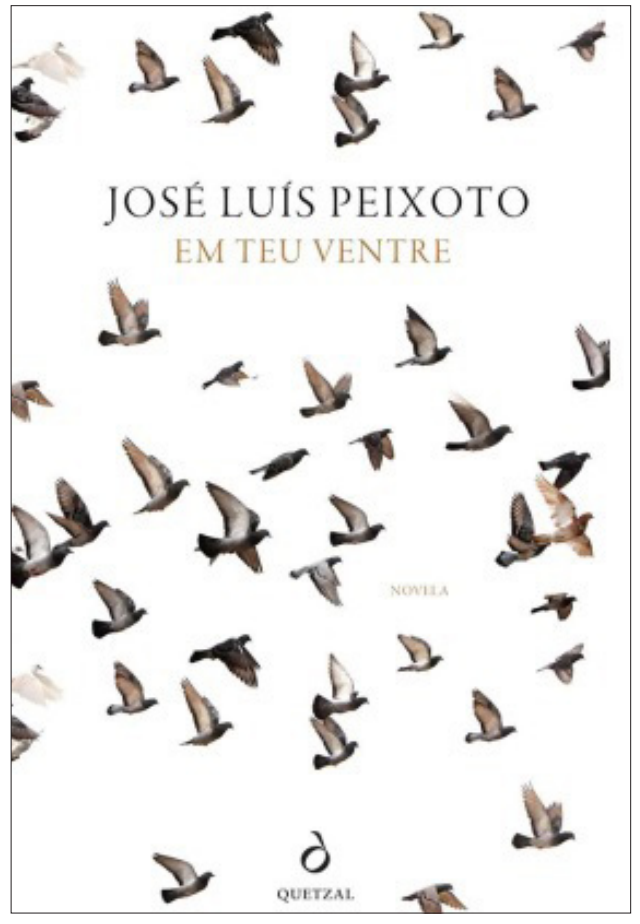

Fonte: Quetzal, 2015; Companhia das Letras, 2016.
Gerard Genette (2006) aponta cinco tipos de transtextualidade: arquitextualidade, paratextualidade, metatexualidade, intertextualidade e hipertextualidade (esta última não desenvolvida neste trabalho). Começo pelos paratextos. Minha leitura foi feita através da edição portuguesa de $E m$ teu ventre, cujo título é o mesmo da versão brasileira. No entanto, há uma diferença entre essas edições para a qual é importante apontar, a capa, como vemos nas imagens (Figuras 1 e 2).

A imagem da esquerda mostra a capa portuguesa, e a da direita, a brasileira. A comparação é autoexplicativa. Na capa da Quetzal, um bando de aves que apenas sugerem o Espírito Santo, mas também a paz, a liberdade, a união, salientando-se a ausência de azul para o céu e a inserção de um espaço branco, bastante iluminador e que pode sugerir a imagem "mais brilhante do que o sol" ". Na edição da Companhia das Letras, optou-se por uma referência direta ao acontecimento que deu origem à crença sobre a aparição de Nossa Senhora, através da fotografia de seus três protagonistas, Lúcia, Francisco e Jacinta. Essa fotografia, atribuída a Joshua Benoliel pela Companhia das Letras, é a mesma da reportagem de Avelino de Almeida publicada na Revista Ilustração Portuguesa (1917), é bastante conhecida entre os cristãos, sobretudo os de fé católica e também no Brasil - país de maior população católica no mundo. Poderia aludir, em vista dessa escolha que nunca é à toa, a uma questão mercadológica, de atração desse público, pois esse tipo de leitor tem um nicho bastante próprio no Brasil. ${ }^{5}$

${ }^{4}$ Forma como era descrita a luz em torno de Nossa Senhora e título de uma das obras utilizadas por José Luís Peixoto, como explico adiante.

Segundo pesquisa da Nielsen Bookscan, para os anos de 2014 e 2015 no Brasil, enquanto houve um crescimento de $9,11 \%$ entre os dois anos em relação ao volume geral de venda de livros, o aumento em relação à autoajuda foi de $42 \%$ números impactados pelos livros de colorir e religiosos, como o de Pe. Marcelo Rossi. A partir de 2015, a crise também incidiu sobre o mercado livreiro, com quedas em volume de impressão, venda e faturamento. No entanto a segunda menor queda entre os quedas em volune de impressão, vence eaturamento. No entanto, a segunda menor queda entre os Analisando o mesmo período, a pesquisa da Fundaç̃o Instituto de Pesquisas Econônicas (Fipe), 
No entanto, a Companhia das Letras já publicou outras obras de Peixoto - Livro (2012), Dentro do segredo (2014), A mãe que chovia (2016) -, autor premiado com o Prêmio Oceanos de Literatura em 2016 com um desses títulos, Galveias, e já agraciado, entre outras láureas, com o Prêmio Literário José Saramago, aos 26 anos, pela obra Nenhum olhar, em 2001. Assim, não me parece ser essa uma estratégia para arrebanhar esses leitores que, é possível afirmar, têm entre suas preferências obras diferentes das de Peixoto, um "romancista sentimental", no dizer de Orhan Pamuk (2011), elaborador mais de imagens poéticas e vazios do que propriamente de fábulas. Por outro lado, não encontro outra justificativa para essa estratégia editorial que, preciso dizer, considero equivocada. Talvez resulte em dialogar com os dois tipos de leitores.

A partir do reconhecimento do intertexto da imagem, o leitor lerá a obra em relação ao acontecimento, certamente. Além disso, nessa capa brasileira há o paratexto, abaixo do título, "Uma reconstituição literária das aparições de Nossa Senhora de Fátima”, que não deixa dúvida sobre o "conteúdo" do livro, em uma espécie de spoiler que não agradou a esta leitora, agradecida por ter lido, sem esse aviso, a edição portuguesa. A palavra "reconstituição", mesmo ao lado de seu adjetivo "literária", é que fere a imaginação, porque não é digna da criação de Peixoto, que não merece esse "re" nem essa "constituição". No entanto, não posso me omitir de dizer que, ao adentrar a história, o leitor brasileiro - mesmo o mais avesso à religião ou mesmo de outra fé - em seguida vai deparar com os nomes do trio de crianças e é bem provável que os reconheça. Já em relação ao leitor português, é possível que ele o perceba ainda antes, ao associar o nome Lúcia à descrição da casa logo no início da novela - pois a casa da pastorinha ainda hoje está lá em Fátima,

pedido do Sindicato Nacional dos Editores de Livros (SNEL) e da Câmara Brasileira do Livro (CBL), também mostrou queda - um decréscimo real no faturamento de $5,2 \%$. No período, chama a atenção o crescimento do mercado de biografias. com "a cal a escamar" (p. 12), aberta ao público, com apetrechos da família, fotos e cheiro de vida. E essa imagem, confesso, só assim se formalizou quando, à página 26, Lúcia se encontra com Jacinta e Francisco, pois a união desses nomes é-me bastante conhecida, criada que fui na fé católica e tendo sido catequista quando adolescente. Além disso, estive em Fátima com minha mãe, que já foi freira, que foi a pessoa quem me narrou, primeiro, a história dos "três pastorinhos", que me encantou tanto que cheguei a pensar em seguir a vocação religiosa quando ainda menina. As ruas, o casario, o clima de Fátima e, principalmente, as casas dos protagonistas, forneceram sensações de todo o tipo para que eu concretizasse a história de Em teu ventre, e é sobre essa edição portuguesa comprada em Lisboa e que traz muitas boas recordações que continuo a falar.

Arquitextualmente, a principal indicação é dada na capa, como é de praxe de muitas edições portuguesas, visto a ficha catalográfica não conter essa informação: trata-se de uma novela. Sobre o gênero, nos aponta Massaud Moisés que, em Portugal, desde o nascimento do romance há certo hibridismo entre ambos, dificultando sua distinção; no entanto, ele arrisca afirmar que a novela deve ser "entendida como uma sucessão linear de episódios ligados por um nexo mais ou menos arbitrário, com vistas à distração do leitor, pelo entrelaçamento do enredo" (2006, p. 125). Somando-se a esse hibridismo que também ocorre no Brasil, a edição de Em teu ventre foi catalogada pela Companhia das Letras como romance, o que me fez pensar sobre as motivações para ser chamado de novela em Portugal. A explicação pode estar justamente nessa condição transtextual a entrelaçar tempos e textos, em que o nexo é justamente a figura da mãe e, também, a vida rural.

Ainda na relação paratextual, ao final do livro, há uma "Nota do Autor" que informa os intertextos (PEIXOTO, 2015, s/p): “[...] Memórias I a VI, da autoria da Irmã Lúcia de Jesus, assim como as transcrições das entrevistas 
e outras referências do livro Era uma senhora mais brilhante do que o sol, pelo Padre João de Marchi." Além disso, há a inclusão de um trecho de Missão abreviada (1868), de Pe. Manuel José Gonçalves Couto, e a citação a um artigo do jornal $O$ Século, de 23 de julho de 1917. A nota do autor inicia-se com afirmação sobre a obra ser "um texto de ficção". As inclusões, embora sirvam apenas como "base" para sua fabulação, justamente fazem desses testemunhos um alicerce para a escrita, e o caso do artigo do jornal que traz uma notícia equivocada confirma essa intenção: "apareceria no dia 13 do corrente a mãe de Jesus Cristo a duas criancinhas" (PEIXOTO, 2015, p. 98). Esta citação direta é realmente do jornal, na data informada e com esse exato erro de que Lúcia reclama para a mãe, que, por sua vez, deve estar irritada porque a notícia, antes, dá ao acontecimento o nome de boato: "o boato de que num determinado ponto da serra de Aire apareceria no dia 13 do corrente a mãe de Jesus Cristo a duas criancinhas" 6 .

É interessante observar que os jornais tiveram um papel importante naquela ocasião em 1917, quando já em julho, nesta primeira notícia de O século, se dava conta do que acontecia em Fátima, dois meses depois da primeira aparição e uma semana depois da terceira. Pelo menos outros doze periódicos publicaram notícias sobre o evento entre julho e dezembro daquele ano. Em outubro, a Revista Ilustração Portugueza fez uma reportagem de quatro páginas que incluíam 11 fotografias que ainda hoje são referência para a memória do evento. Os jornais têm um aspecto importante nessa memória coletiva, pois registram, não deixam esquecer; seus leitores fazem das palavras no papel o próprio repertório de sua memória sobre o evento, como se o tivessem experienciado.

${ }^{6}$ Essa citação foi retirada do jornal Expresso, reportagem de 13 de maio de 2017, por ocasião do
centenário da aparição. Disponível em: <http://expresso.sapo.pt/sociedade/2017-05-13-0-sol-bailoucentenarrio da aparição. Disponivel em: <http://expresso.sapo.pt/sociedade/2017-0
À página 53, também em formato diferente demarcando a intertextualidade, há uma citação direta da obra Missão abreviada, de Pe. Manuel José Gonçalves Couto, como se pode ver, idêntica ao original e respeitando a ortografia da época.
Figuras 3 - Trecho digitalizado de Em teu ventre, p. 53

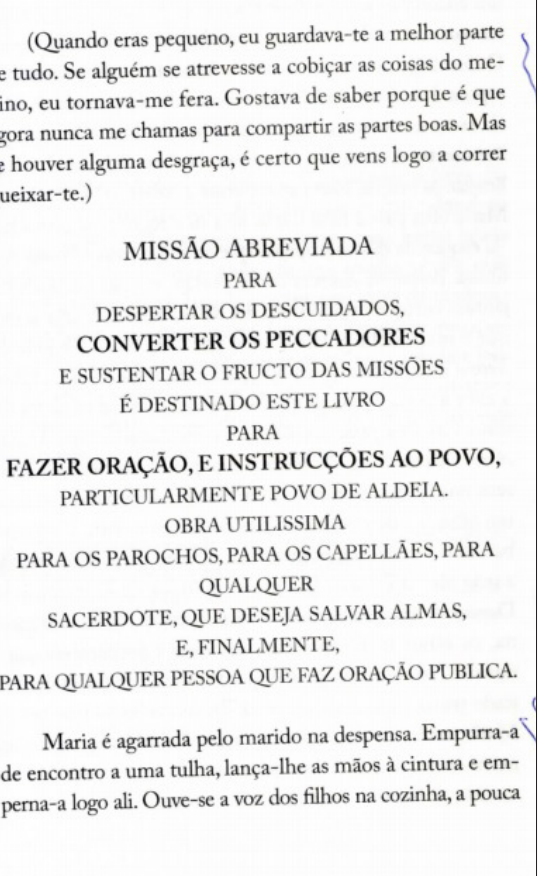

Fonte: Quetzal, 2015
Figuras 4 - Página digitalizada de Missão abreviada, 1868, p. 7

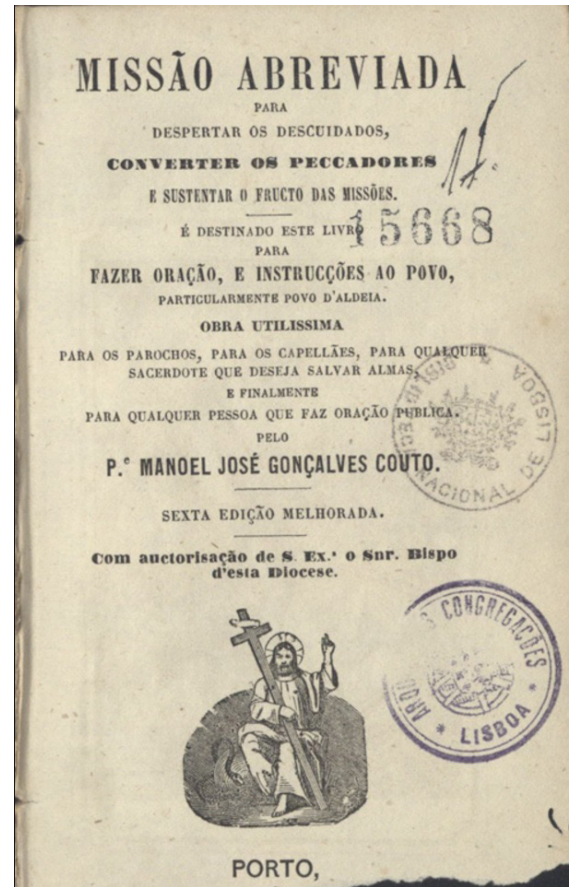

Fonte: Biblioteca Nacional Digital de Portugal, 2017.
Seguindo a linha paratextual - também intertextual - há duas epígrafes em uma página anterior ao início da novela: uma de Alain Badiou, da página 89 de seu livro $O$ século (coincidentemente o mesmo nome do jornal), de 
2007; e uma de Irmã Lúcia de Jesus, retirada de suas memórias, publicada em Memórias I.

Figura 5 - Epígrafes de Em teu ventre

\begin{tabular}{|} 
«Claro que é uma mentalidade infantil, mas ela ensina- \\
-nos a levantar o nosso olhar para o Céu, onde sabemos \\
que está Deus nosso pai, a Mãe bendita que Ele nos deu \\
e vela por nós, os Anjos que Ele criou e destinou para \\
guiar-nos e conduzir-nos nos caminhos da vida.» \\
Irmã Lúcia de Jesus, Quinta Memória \\
«Nada pode atestar que o real é real, nada senão o sistema \\
de ficção no qual ele desempenhará o papel de real.» \\
Alain Badiou, O Século
\end{tabular}

Fonte: Quetzal, 2015.

A intertextualidade também é bastante alusiva e começa já na primeira página do primeiro capítulo "Maio" - outra referência ao acontecimento que só é percebida quando o leitor reconhece a fábula em torno da qual gira a novela -, e ainda também no aspecto formal (Figura 6).
Figura 6 - Imagem digitalizada de Em teu ventre, p. 11

\begin{tabular}{|cc|}
\hline 1 Tudo começa pela & minei foi: negar esperança é \\
esperança. & uma ação contra a natureza. \\
${ }^{2}$ Antes dos objetos estão os & ${ }^{15}$ Todos os seres, principal- \\
gestos que lhes dão forma, & mente os que possuem pele, \\
${ }^{3}$ antes dos gestos estão & têm o direito inequívoco \\
as ideias, & a alguma esperança. \\
${ }^{4}$ antes das ideias estão & ${ }^{16}$ O uso que lhe dão é a sua \\
as emoções, & individualidade. \\
${ }^{5}$ antes das emoções estão & ${ }^{17}$ Falo de quando criei a natu- \\
os sentidos, & reza, como se esse trabalho \\
${ }^{6}$ antes dos sentidos está & estivesse acabado. \\
a existência nua, & ${ }^{18}$ As palavras são imperfeitas \\
${ }^{7}$ contemplação cega, & quando tentam dizer aquilo \\
memória cega, & que é maior do que elas. \\
${ }^{8}$ antes da existência está & ${ }^{19}$ São imperfeitas também \\
a esperança. & quando tentam dizer aquilo \\
${ }^{11}$ Sou eu quem o diz. & que parece ínfimo, depen- \\
${ }^{12}$ Se há proposta de vida, essa & dendo da proporção. \\
certeza contém esperança. & ${ }^{20}$ Nesse caso, as palavras são \\
${ }^{13}$ Sem esperança, há apenas & dedos que tentam apanhar \\
morte: no presente e no & uma migalha, fazem \\
futuro. & a forma de beliscá-la, \\
${ }^{14}$ Quando criei a natureza, & mas deixam-na lá, como \\
a primeira regra que deter- & se fossem inúteis. \\
\hline
\end{tabular}

Fonte: Quetzal, 2015. 
O formato sugere a textualidade da Bíblia, imitando o discurso do Gênesis e aproximando a voz desse narrador à de Deus, ambos como criadores de um universo - ambos pela palavra. Se no Gênesis temos uma voz em terceira pessoa, que advém de uma oralidade ancestral presente em várias religiões, aqui há uma voz em primeira pessoa que fala de sua criação e, que, assim, chamaremos de escritor, diferenciado da voz do narrador onisciente. Poderíamos chamar a essa voz de orador, visto que "imita" o discurso do mito; no entanto, essa escolha se dá em vista de que a relaciono à figura mesma do escritor José Luís Peixoto, como explico a seguir. A possibilidade de espelhamento com Deus é reforçada no capítulo seguinte a este, que começa dizendo "Deus continua a falar" (p. 12), para apontar para a casa de Lúcia, importante espaço da história, como o centro de um universo que se está a formar, e tecendo uma relação com a voz anterior.

Nas orações 19 a 20 desse trecho, a metalinguagem se faz presente, quando a voz desse escritor faz referência ao fato de que as palavras não conseguem dizer tudo, sugerindo que essas mesmas palavras do livro não vão alcançar nem "aquilo que é maior do que elas" - a esperança, a natureza - e "aquilo que parece ínfimo", as migalhas da vida. Mais adiante Maria, mãe de Lúcia, vai dizer que as pessoas que acorrem ao povoado em vista da aparição "querem por força uma migalha de esperança perante o desespero" (p. 133). Noutra aparição desse escritor, ele entrelaça a urdidura do mundo à escritura, fazendo espelhar na sua mãe todas as mães do mundo: "[P]or isso, mãe, por amor e respeito, pus um pouco de ti em tudo o que fiz. / Não se pode olhar para qualquer ponto desta obra sem te ver" (p. 35). Essa voz surge justamente em seguida ao momento da primeira aparição: "Eis o teu rosto iluminado por esta hora de maio." (p. 34) - e sugere, assim, a tríade Deus, Espírito Santo, Jesus - amalgamada em torno desse escritor, visto que a mãe é uma só, espelhada na imagem da aparição: “Ao filho autêntico, basta fechar os olhos para encontrar o rosto da sua mãe. / A fronteira que separa o dentro do fora é vaga de propósito" (p. 34).

Além da voz desse criador inaugural, o escritor, há um narrador em terceira pessoa, onisciente - claro! - que mistura a sua voz com a dos personagens sem qualquer sinal gráfico para separá-las. Ele também penetra nos pensamentos da mãe de Lúcia, embora sempre com cautela:

Maria começa por duvidar do seu entendimento, parece-lhe que essas palavras não existiram. É só depois de recapitular esses instantes que se enraivece, seria talvez capaz de partir a mesa com um murro de mão fechada. Em vez disso levanta-se e empurra os ombros dos sobrinhos, mete-os na rua (p. 38).

Esse "parece" se repete mais adiante: "Maria não responde ao marido, parece que não o ouve, apenas vê as cartas que estão em cima da mesa e as cartas que tem na mão [...]" (p. 50). o "talvez" também se repete: "Talvez por hábito, essas lágrimas trazem a injustiça de se sentir sozinha” (p. 132). A onisciência, assim, se mostra muito mais atrelada a uma presença que vê, por exemplo, as expressões da mãe e, então, adivinha: “Todos riem. Maria olha para a filha Lúcia, vê-a rir e regozija-se por achá-la esquecida dessas tropelias que arranjou com a Nossa Senhora" (p. 54).

Esse narrador onisciente alterna seus longos parágrafos com frases curtas que são como que pequenas parábolas de tom ancestral e coletivo, eis que separadas por espaços dos outros parágrafos: "As chamas afundamse no interior das velas" (p. 46); "Os rostos das pessoas têm palavras à espera" (p. 78); "São negras as brisas que atravessam a noite" (p. 79); “A sombra das árvores do jardim é antiga" (p. 108); "Talvez o calor que a terra emana seja uma das formas que a terra tem de se exprimir" (p. 109). Algumas dessas orações separadas falam do efeito de uma ação importante e, por isso, parecem, também, sentenças atemporais: "O padre não acredita" (p. 91); "As cadeiras a arrastarem-se" (p. 98); "A transpiração arrefece 
devagar sobre a pele." (p. 100); “Todas as coisas estão limpas como se fossem novas" (p. 106); "Lúcia, estás a pensar em quê?" (p. 119); "Os ramos das oliveiras querem falar de quê?" (p. 127); "Os talos das couves são feitas de lenha rude" (p. 129); "As varetas dos guarda-chuvas escorrem fios de água" (p. 156). Essas imagens poéticas de um universo cotidiano e coletivo traduzem todo o tom da obra.

Além da perspectiva do narrador sobre a mãe de Lúcia, há a voz de outra mãe, em primeira pessoa, que é destacada do texto através de parênteses:

Figura 7 - Trecho de Em teu ventre, p. 15

(Duvido que sejas capaz de me imaginar com dez anos. Já fui nova, sabias? Quando nasceste, em setembro, eu tinha trinta e dois anos feitos em junho. Talvez consigas suspeitar o que foi para mim ter-te com trinta e dois anos, até acredito nisso. Lembro-me de estares na minha barriga, nos últimos meses era um barrigão, mas tu não és capaz de me imaginar com dez anos, duvido. Não sou essa menina que imaginas quando tentas imaginar-me com dez anos. Fui uma menina que nunca conhecerás.)

Fonte: Quetzal, 1915

Essa mãe dialoga diretamente com o escritor, seu filho, muitas vezes, fazendo referência às suas vivências. José Luís Peixoto nasceu no mês de setembro, como esse escritor que fala, um biografema que cola ambas as vozes, transformando a escritura e apontando para essa voz como a da mãe do escritor, e é em vista disso a escolha por assim nomear a voz desse deus inaugural do discurso. Isso é reforçado pelas várias vezes em que ela, a mãe, faz referência à escrita, por exemplo: "Pela maneira como escreves" (p. 22); “Talvez porque escreves livros” (p. 83). Em um desses diálogos entre o escritor e sua mãe, o espelhamento entre ele e Deus, ela e Nossa Senhora, e entre as duas obras - o mundo e o livro - é reforçado: "Peço-te perdão, mãe, luz mais incandescente do que o sol"; "(Não precisas de pedir desculpa. Perdoei-te antes de a luz se separar das trevas, antes mesmo de as trevas cobrirem o abismo. Ainda não tinhas escrito uma única palavra e já eu te tinha perdoado. Perdoei-te antes do verbo.)" (p. 143-144). Confesso que essa é uma das imagens mais poéticas de um diálogo que eu já encontrei na literatura, mas eu sou mãe - e eu preferia chamá-la de linda, emocionante, forte, com toda a subjetividade possível de leitora.

Esses comentários entre mãe-leitora e filho-escritor mostram-se como metatextualidade, outra estratégia transtextual que, aqui, promove a reconstrução de uma memória que é coletiva - materna, reconhecida por uma cultura e por uma família - e individual, porque é específica da relação entre ambos. Surge aí uma mãe que aconselha e faz cobranças, muito próxima à mãe de Lúcia, mas também uma mãe que traz memórias de afetos e cuidados: "(Quando eras pequeno, eu guardava-te a melhor parte de tudo. [...]" (p. 53)

Nesse sentido, as memórias individuais da mãe do escritor, presentificadas pela escritura, vão sendo entrelaçadas com as memórias de outra mãe e sua filha - Maria, a que pariu Maria dos Anjos, Teresa de Jesus, Manuel, Glória de Jesus, Carolina de Jesus, Maria Rosa e Lúcia. A mãe do escritor também comenta muitas vezes as palavras do narrador onisciente, como se tivesse anotado no próprio texto a sua impressão sobre o que ele conta, o que traz à luz uma nova tríade: Deus, o escritor e o narrador - como 
criadores - em uma só pessoa. Por exemplo, em um dos trechos onde o narrador onisciente descreve uma reunião à mesa para o almoço da família em um feriado santo, ela diz em seguida: "(À hora de almoço, só precisavas de ocupar o teu lugar à mesa. Mesmo assim, ainda te achavas no direito de me acusar de sal a mais ou a menos. [...])" (p. 48). Os parênteses demarcam sua localização em outro espaço e tempo, mas eu uma mesma história, permitindo que ela, por ser mãe, invada a diegese.

Nessas construções metaficcionais, porque falam do processo de criar pela palavra, também se mostra uma das características da obra de Peixoto bastante presente no livro: a construção de imagens a partir do cotidiano familiar, sobretudo aquele que é de sua experiência, a vida interiorana, rural. O sacrifício das galinhas ${ }^{7}$, o pastoreio, a lida na casa, a colheita, os rituais religiosos, o cão a roçar as pernas das pessoas, os dias e as noites, os cheiros das coisas, os alimentos:

0 cheiro das figueiras, copas intrincadas de folhas carnudas, enche o ar fresco do quintal. São figos doces, perfumados por juventude. [...] Já não bastam as esmolas que toda a vida deu aos esfarrapados: as duas mãoscheias de batatas novas, porções de feijões e grãos-de-bico, azeite vertido diretamente da almotolia para garrafas sujas, fatias de pão com queijo de ovelha, tigelas de azeitonas retalhadas ou, mesmo, lascas de carne da salgadeira (p. 132-133).

Muitas vezes Lúcia está com a família em torno da mesa - são 23 referências à palavra - e a cozinha ${ }^{8}$ é o espaço do encontro da família, sobretudo dos desacertos - "O ar da cozinha não tem tempo, só tem sombra" (p. 37).É à mesa que a mãe faz a leitura do jornal, interroga a filha, demonstra 7 Em Livro, romance de Peixoto, há a descrição da matança de um porco que transforma a crueza da
realidade, em todos os seus detalhes, em imagem poética - cheia de sons, cores e texturas.
${ }^{8}$ Peixoto tem uma crônica bastante poética que se coloca como uma receita e fala da experiência de
preparar o pão-de-ló como sua avó fazia. Disponível em: <http://upmagazine-tap.com/pt_artigos/ receita-de-pao-de-lo/>. Acesso em: set. 2017. insatisfação com os rumos dos acontecimentos e com as atitudes do marido. Também é na cozinha que geralmente se dá o encontro entre a família e a irmã adotiva - a órfã, como é chamada pelo narrador onisciente. Ela está ali para assinalar que mãe é aquela que gera, não aquela que cria, pois a mãe de Lúcia manifesta sempre sua irritação com a menina, tratando-a como uma serviçal, diferente do modo como trata as filhas: "[A] órfã tremelica os olhos, prepara-se para uma pedrada que não sabe de onde virá. Há um compasso de silêncio." (p. 25). A menina é órfã de mãe, mas o pai está presente na história, o que caracteriza ainda mais a importância da mãe, ou a falta dela - a órfã está sempre assustada, em silêncio e à espera.

Os pensamentos de Lúcia, seus diálogos com o mundo silencioso da solidão e suas orações, são escritos em itálico. Nesses trechos, a natureza, os animais, os objetos da rotina, parecem ter uma voz única - que é dela própria e parecem substituir o não-dito por Nossa Senhora, já que suas mensagens não aparecem na novela. Por exemplo, quando Lúcia ensaia a maternidade com um cordeirinho recém-nascido que pega ao colo: "Queres colo? / Obrigado, menina. Ainda estamos longe de casa? / É já a seguir àquela esquina, é já ali, mas deixa-te ir. / Ai, o teu colo sabe tão bem, menina" (p. 56). Aqui, parece haver a sugestão de que ela escuta aquilo que não é dito ao colocar as suas palavras na boca do silêncio.

Assim, em seus monólogos internos, Lúcia dá voz a interlocutores silenciosos como ela - uma pedra, uma pena, um lencinho de papel, um cão -, "Não te estou a ver, cão pequenino e chato" (p. 46), tanto quanto o dá às suas orações: "Ave, Maria, cheia de graça, o Senhor é convosco" (p. 51). Seus pensamentos, no entanto, assemelham-se à poeticidade do narrador onisciente ou mesmo do escritor, e não parecem refletir a voz de uma menina, sugerindo uma aproximação, desta feita, entre os filhos Deus-Jesus, o narrador e Lúcia -, como neste trecho onde ela fala com a noite. 
Figura 8 - Trecho de Em teu ventre, p. 29

Após estas palavras sussurradas, Lúcia levanta o olhar sentido para Glória. Então, em silêncio, Lúcia fala à noite:

Não te custa, eu sei. Se quiseres, escolhes um momento entre todos os que passam pelas estrelas lá fora, pela superfície do céu que é apenas negra, escolbes um momento entre todos os que passam aqui pelo lume, pelas brasas que adormecem ou morrem, cobertas por uma camada de cinza branca, que passam pelos intervalos em que não se escutam talheres a bater nos pratos, pelos olhares, escolhes um momento e ficas nele, se quiseres. Será como se, a meio do caminho, decidisses olhar em volta. Não te peço que deixes de chegar onde tens de ir, apenas que esperes um pouco, quase nada, para ti é nada, tens a eternidade inteira, tens os tempos dos tempos, peço-te apenas que esperes pelo meu pai. Espera pelo meu pai, por favor.

Mas a noite, como se não tivesse ouvido, segue lenta e contínua. Lúcia pensa que o corpo da noite é demasiado grande. Talvez a noite queira parar e não consiga. Lúcia tem pena da noite.

Fonte: Quetzal, 1915

Em outro trecho, quando Lúcia conversa com uma folha, percebe-se a intertextualidade com os escritos de Irmã Lúcia, como podemos ver comparando os trechos com o texto a seguir.
As galinhas conformaram-se nos seus poisos. As estrelas furam já o céu, olhinhos que tudo veem. Lúcia tem a cadela a querer-se embaraçar nos seus tornozelos. A rapariga baixa-se e empurra devagar esse vulto sem nome, faz-lhe ver que esta não é hora desse namoro. De pé, diante da aragem fresca que atravessa a copa da figueira, Lúcia resda aragem fresca que atravessa a copa da figueira, Lúcia res-
pira e puxa um ramo, macio na mão, maleável. Escolhe uma folha grossa, grande, mãe de outras folhas.

Estou tão cansada, folha.

Estamos todos.

Acho que estou mais cansada do que todos.

Aqueles que estão mesmo cansados acham sempre isso.

Se eu te contar um segredo, prometes guarda-lo?

Posso tentar, mas não depende só da minha vontade.

Como assim?

Os segredos passam por qualquer fresta, säo mais fuidos do que a água, mais informes do que o ar. Podemos fazer tudo para guardar um segredo, mas ele acaba por encontrar caminho para se esvair.
enardar

Fonte: Quetzal, 1915.

Mas a quem o contarias, folha?

Näo o contaria fosse a quem fosse, mas podia deixar escapar um laivo dessa noticia na seiva e, logo depois, todas as folhas desta figueira saberiam e, no dia seguinte, todos os pássaros saberiam. Pouco faltaria para que o mundo inteiro soubesse o teu segredo.

Ninguém pode saber, folha. É um segredo. Como posso guardá-lo de todos?

A única maneira é näo o contares a ninguém e esperar que não to roubem dos olbos

Estou tâo cansada, follha, tão cansada.

Estamos todos, menina.

Cheguei à noite verdadeiramente cansada de tantas perguntas e interrogatórios. Estes nem com a noite acabaram. Várias pessoas, por não terem podido interrogar-me, ficaram para o dia seguinte, à espera de vez. Quiseram ainda, algumas, falar-me ao serão; mas eu, vencida pelo cansaço, deixei-me cair no chão a dormir. Graças a Deus, o respeito humano e o amor próprio, em aquela altura, ainda os não conhecia; e, por isso, estava à vontade diante de qualquer pessoa, como se estivesse com meus pais. No dia seguinte, continuaram-se os interrogatórios ou, para melhor dizer, nos dias seguintes, porque, desde então, quase todos os dias iam várias pessoas implorar a protecção da Mãe do Céu à Cova da Iria e todos queriam ver os videntes, fazer-lhes as suas perguntas e rezar com eles o seu Terço. Às vezes, sentia-me tão cansada de tanto repetir o mesmo e de rezar, que procurava um pretexto para me escusar e escapar (DE JESUS, 2007, p. 97). 
A canseira da menina encontra a canseira da adulta, muitos anos depois, em uma confissão que a aproxima da insatisfação de Maria, sua mãe, naqueles dias de muitos mistérios e dúvidas - mas de uma mulher que não esquece a "mentalidade infantil", como aponta a epígrafe do livro. 0 narrador onisciente respeita o espaço coletivo da fábula: ele não ousa interferir no instante da aparição, como se não tivesse o direito de falar de um milagre que ele não viu: "Mas, de repente, Lúcia levanta-se. Os primos seguem-na. Lúcia e os primos avançam retos, desconsideram veredas, e, sem precisarem de palavras, ficam parados diante de uma pequena azinheira." (p. 33). "Sem precisarem de palavras", cabe aos leitores imaginar aquilo que talvez já faça parte de sua memória individual em um gesto contínuo de transtextualidade entre seu repertório e o texto. E assim o narrador se cala - ofuscado pela luz, temente à traição da memória ou respeitoso diante dos "corpos transparentes" que são as palavras.

Uma das questões intrigantes da obra de Peixoto é o fato de que ele utiliza, como referência, conforme aponta naquele posfácio chamado de "Nota do Autor", apenas as Memórias de I a IV de Irmã Lúcia, enquanto que é na V e na VI memórias, publicadas em Memórias II, que estão os escritos sobre o pai e a mãe. A exceção é o trecho da epígrafe, apontada como da Quinta Memória, mas esses são escritos sobre o pai de Lúcia, o que se confirma a intenção de Peixoto de se afastar da Sexta Memória. É uma escolha acertada, afinal, mexer nas memórias de Lúcia sobre sua mãe é balouçar demais na moldura da ficção - e penetrar em um terreno que sabemos nem mesmo aquele citadíssimo psicanalista vienense conseguiu exaurir. E esta é uma obra de ficção, repleta de memórias, repleta de imagens que qualquer leitor - porque somos todos filhos - é capaz de concretizar, seja ele cristão ou não. Basta sua crença na literatura, no verossímil, no poético.

\section{Referências}

ALMEIDA, Avelino de. O milagre de Fátima. Revista Ilustração Portuguesa, n. 610, 29 out. 1917, p. 353-356. Disponível em: <http://hemerotecadigital.cm-lisboa.pt/OBRAS/ IlustracaoPort/1917/N610/N610_master/N610.pdf>. Acessado em: set. 2017.

AMARAL, Gonçalo. Maddie, a verdade da mentira. Lisboa: Guerra e Paz, 2008.

BADIOU, Alain. O século. São Paulo: Ideias e Letras, 2007.

BARTHES, Roland. A câmara Clara. Rio de Janeiro: Nova Fronteira, 1984.

BURPO, Todd; VINCENT, Lynn. O céu existe mesmo. Lisboa: Lua de Papel, 2011.

COMPANHIA DAS LETRAS. Portal on line. "A viagem do elefante." S/D. Disponível em: <https://www.companhiadasletras.com.br/detalhe.php?codigo=12696>. Acesso em: Set. 2017

CRISTÓVÃO, Paulo Pereira. A estrela de Joana. Lisboa: Presença, 2007

ECO, Umberto. Quase a mesma coisa: Experiências de tradução. Rio de Janeiro: Record, 2007.

GARCÍA MÁRQUEZ, Gabriel. Cem anos de solidão. Rio de Janeiro: Record, 2000.

GENETTE, Gerard. Palimpsestos: a literatura de segunda mão. Cadernos do Departamento de Letras Vernáculas. Belo Horizonte: FALE/UFMG, 2006.

GILBERT, Elizabeth. Comer, orar, amar. Lisboa: Bertrand, 2006.

GILBERT, Elizabeth. Comer, rezar e amar. Rio de Janeiro: Objetiva, 2008

Irmã Lúcia de JESUS. Memórias da Irmã Lúcia I. Fátima: Secretariado dos Pastorinhos, 2007.

JORNAL EXPRESSO. "Os 50 livros mais vendidos nos últimos cinco anos." Publicação on line. Set. 2012. Disponível em: <http://expresso.sapo.pt/cultura/Livros/os-50-livrosmais-vendidos-nos-ultimos-cinco-anos=f750972>. Acesso em: set. 2017.

LIPOVETSKY, Gilles. A era do vazio: ensaios sobre o individualismo contemporâneo. São Paulo: Manole, 2005.

LIPOVETSKY, Gilles. O mundo hipermoderno. São Paulo: Edições 70, 1911.

LUKÁCS, George. A teoria do romance: um ensaio historicofilosófico sobre as formas da grande épica. São Paulo: Duas Cidades, 34, 2000. 
MOISÉS, Massaud. A Literatura portuguesa. São Paulo: Cultrix, 2006.

NATÁRIO, Anabela. “O sol bailou pouco nos jornais. Fátima nas notícias de há 100 anos”. Expresso online, 13 mai., 2017. Disponível em: <http://expresso.sapo.pt/ sociedade/2017-05-13-0-sol-bailou-pouco-nos-jornais.-Fatima-nas-noticias-de-ha100-anos>. Acesso em: set. 2017.

NIELSEN BOOKSCAN. "Consumo". Pesquisas sobre o mercado editorial. Disponível em: $<$ http://www.nielsen.com>. Acesso em jun. 2017.

PEIXOTO, José Luís. "Receita de pão-de-ló”. Tap Magazine. 1 set. 2014. Disponível em: <http://upmagazine-tap.com/pt_artigos/receita-de-pao-de-lo/>. Acessado em: set. 2017.

PEIXOTO, José Luís. Em teu ventre. Lisboa: Quetzal, 2015.

PEIXOTO, José Luís. Em teu ventre. São Paulo: Companhia das Letras, 2016.

PEIXOTO, José Luís. Livro. São Paulo: Companhia das Letras, 2012.

ROSA, João Guimarães. Grande sertão: veredas. Rio de Janeiro: Livraria José Olympio Editora, 1965.

SANTOS, José Rodrigues dos. A fórmula de Deus. Lisboa: Gradiva, 2006.

SANTOS, José Rodrigues dos. Codex 632. Lisboa: Gradiva, 2005.

SANTOS, José Rodrigues dos. O anjo branco. Lisboa: Gradiva, 2010.

SANTOS, José Rodrigues dos. O sétimo selo. Lisboa: Gradiva, 2007.

SANTOS, José Rodrigues dos. O último segredo. Lisboa: Gradiva, 2011.

SARAMAGO, José. A viagem do elefante. São Paulo: Companhia das Letras, 2008.

SARAMAGO, José. Caim, Lisboa, Caminho Editorial, 2009.

SARAMAGO, José. História do cerco de Lisboa. Porto: Porto Editora, 1989.

SARAMAGO, José. Memorial do convento. Lisboa: Caminho Editorial, 1982.

SARAMAGO, José. O evangelho segundo Jesus Cristo. Lisboa, Caminho Editorial, 1991.

SINDICATO NACIONAL DE EDITORES DE LIVROS. "Pesquisa Produção e Vendas do Setor Editorial Brasileiro (Fipe)”. Disponível em: <http://www.snel.org.br>. Acesso em jun. 2017.

TAVARES, Miguel Sousa. Rio das flores. Alfragide: Oficina do Livro, 2008.
YOUTUBE. "Os romances históricos são dos livros mais procurados pelos portugueses." Vídeo on line. Fev. 2013. Disponível em: <https://www.youtube.com/ watch?v=pGOTDbUcfMk>. Acesso em: jul. 2017.

Recebido em 12/01/2018.

Aceito em 28/03/2018. 